\title{
Reliability and dimensionality of the Short Alcohol Dependence Data (SADD) questionnaire in a clinical sample of hospitalized patients: using the SADD in a general hospital setting
}

\section{Confiabilidade e dimensões do questionário Short Alcohol Dependence Data (SADD) em uma amostra de pacientes hospitalizados: uso do questionário SADD em hospital geral}

\author{
Leonardo Quicoli Rosa-Oliveira, ${ }^{1}$ Paula de Figueiredo Presti, ${ }^{1}$ Irene Reali Antunes, ${ }^{1}$ Giovana Canale Carbonari, ${ }^{1}$ \\ Ana Carolina Imada, ${ }^{1}$ Marilia Yuri Maeda, ${ }^{1}$ Dartiu Xavier da Silveira, ${ }^{1}$ Juliana Doering-Silveira ${ }^{1}$ \\ 1 Department of Psychiatry, Universidade Federal de São Paulo (UNIFESP), São Paulo, SP, Brazil
}

\begin{abstract}
Objective: To assess the internal consistency and dimensionality of the Short Alcohol Dependence Data questionnaire in a general hospital sample. Method: A cross-sectional study was carried out involving 169 randomly selected inpatients of a general hospital in São Paulo, Brazil. A Portuguese version of the 15-item Short Alcohol Dependence Data questionnaire was applied together with a questionnaire to assess demographic and anthropometric data. Results: The internal consistency of the Short Alcohol Dependence Data as measured using Cronbach's alpha was 0.79 , indicating that the items of the questionnaire are related to the same construct. Principal Component Analysis of the scale resulted in a five-dimension solution accounting for $69.6 \%$ of the total variance. The mean score of the Short Alcohol Dependence Data in this sample was 7.96 ( $S D=6.8)$. Conclusion: The adapted version of the SADD seems to retain the characteristics of the original version. The internal consistency of the instrument suggests that its questions converge to the same construct. The factorial solution reflects different dimensions that correspond to distinct aspects of the alcohol dependence syndrome.
\end{abstract}

Descriptors: Alcohol; Questionnaires; Substance-related disorders; Factor analysis, statistical; Scales

\section{Resumo}

Objetivo: Investigar a consistência interna e a dimensionalidade do questionário Short Alcohol Dependence Data utilizado em pacientes de um hospital geral. Método: Foi utilizada a versão de 15 questões do Short Alcohol Dependence Data em um estudo de corte transversal envolvendo 169 pacientes aleatoriamente selecionados internados em um hospital geral universitário em São Paulo, Brasil. Resultados: A consistência interna do Short Alcohol Dependence Data medida pelo alfa de Cronbach foi 0,79, sugerindo que os itens do questionário convergem para um mesmo construto. $A$ análise do componente principal da escala resultou em uma solução de cinco dimensóes que explicam 69,6\% da variabilidade dos dados. A média das pontuações do Short Alcohol Dependence Data foi 7,97 $(D P=6,8)$. Conclusão: A versão adaptada do Short Alcohol Dependence Data parece manter as características do questionário original. A consistência interna elevada sugere que as questóes convergem para um mesmo construto e a solução fatorial reflete a existência de distintas dimensōes que correspondem aos diversos aspectos da sindrome de dependência do álcool.

Descritores: Álcool; Questionários; Transtornos relacionados ao uso de substâncias; Análise fatorial; Escalas

\section{Introduction}

The Short Alcohol Dependence Data (SADD) questionnaire is used to measure the severity of alcohol dependence. ${ }^{1}$ The SADD evaluates behavioral and subjective aspects of alcohol dependence, with adequate construct validity and high correlation with other instruments. Based on the Edwards and Gross formulation of the Alcohol Dependence Syndrome, ${ }^{2}$ it is a 15 -item self-report questionnaire that provides a measure of the severity of alcohol dependence within a continuum ranging from mild problem drinking to severe alcohol dependence. The developers suggest that the SADD is particularly sensitive for individuals within the mild to moderate problem range, since it includes cognitive and behavioral ratings of problem drinking. ${ }^{2}$

Concerning the reliability and validity of the scale, a reasonable internal consistency was reported in a split-half reliability study 
that found a significant correlation between the total scores in oddand even-numbered questions. ${ }^{1}$ A confirmatory factor analysis was conducted by Bunting and Raistrick concluding that the SADD measures a single construct: the alcohol dependence syndrome. ${ }^{3}$ The construct validity of the SADD has been investigated in several studies in which the SADD was compared to a variety of measures related to the alcohol dependence syndrome. ${ }^{3}$

The applicability of the SADD has been previously investigated in a Brazilian study. ${ }^{4}$ Comparing the scores of the English version and the translated Portuguese version administered two weeks apart to a sample of bilingual university students, the authors found that the Brazilian version of the SADD and the original English version were highly correlated. A high correlation was also observed between the self-reported and the clinician-administered versions of the scale. ${ }^{4}$ The SADD seems to be relatively immune to social-cultural influences and can be used in different settings. ${ }^{2,4}$

The objective of the present study was to investigate the internal consistency and dimensionality of a Portuguese version of the widely used 15-item SADD questionnaire when administered to the inpatients of a general hospital in São Paulo, Brazil.

\section{Method}

\section{Sample}

One hundred sixty-nine (169) participants of both genders were randomly selected among the inpatients of a general hospital in São Paulo, Brazil.

\section{Instrument}

The participants completed the 15-item Portuguese version of the SADD. ${ }^{2}$ The following scores were used to quantify the severity of alcohol dependence: 0 , no dependence; $0-9$, mild dependence; 9-19, moderate dependence; and 20-45, severe dependence.

\section{Procedures}

Patients were interviewed by medical students of the Universidade Federal de São Paulo, Brazil, and completed the questionnaire during hospitalization, after receiving information on the research objectives. Participants were requested to sign an informed consent stating that the data obtained would be fully confidential, in accordance with the standards of the Research Ethics Commission of the Universidade Federal de São Paulo (process number 1177/06).

\section{Statistics}

Internal consistency was assessed using Cronbach's alpha coefficient. Squared multiple correlation coefficients (SMC) were calculated for each item of the scale. Items with a squared multiple correlation coefficient under 0.15 were considered as poorly correlated with the scale as a whole. ${ }^{5}$ The data were submitted to Principal Component Analysis. Instead of trying to obtain distinct non-correlated factors by using orthogonal rotation, we used varimax rotation to check whether factors were indeed poorly correlated, suggesting the existence of relatively "independent" dimensions. Based on the Kaiser-Guttman criterion, factors with eigenvalues higher than 1.0 were retained for subsequent varimax rotation. Questionnaire items loading $\geq 0.40$ were included in the final factor solution. ${ }^{6}$ The analysis was performed using the Statistical Package for the Social Sciences.

\section{Results}

The sample consisted of 83 men (49.1\%) and 86 women $(50.9 \%)$, with a mean age of $47.7(\mathrm{SD}=15.6)$ years. Subjects were predominantly Caucasian (65.1\%), married (54.4\%), unemployed (64.5\%), and most of them (88.7\%) had completed at least elementary school.

In the total sample, $115(68.0 \%)$ patients scored zero on the SADD, 39 (23.1\%) had a low level of alcohol dependence (scores between 1 and 9), 10 (5.9\%) had moderate dependence (scores between 10 and 19), and only 5 (3.0\%) had a high level of alcohol dependence (scores between 20 and 45). The mean score of the SADD was $7.96(S D=6.8)$ within the sub-sample of alcohol dependents.

The SADD coefficient of internal consistency was 0.79 . None of the questions presented low squared multiple correlation coefficients (SMC), indicating that all the items were important components of the set.

The Principal Component Analysis of the scale resulted in a five-dimension solution. Items 2, 3, 6, and 8 made up the first factor, corresponding to a dimension related mainly to loss of control and inappropriate drinking planning $(\mathrm{CEV}=28.39 \%)$. Items 7,12 , and 13 were grouped in a second factor related to dealing with short-term consequences and problems derived from alcohol use $(\mathrm{CEV}=14.18 \%)$. Items 4, 5, 14, and 15 composed a third factor regarding both inappropriate planning of drinking habits and adverse consequences of drinking ( $\mathrm{CEV}=11.48 \%)$. Items 10 and 11 were associated in a fourth factor related to withdrawal symptoms $(\mathrm{CEV}=8.29 \%)$. Finally, items 1 and 9 corresponded to a last dimension concerning the inability to get rid of urges associated with alcohol consumption, expressed by obsessive thoughts related to drinking and by the impossibility of having proper control over the alcohol intake (CEV $=7.21 \%)$.

The composition of the five factors obtained through Principal Component Analysis, the explained variances of the factors, and the item loadings of the SADD are shown in Table 1. Overall, most of the items of the SADD had an adequate performance, including the factor solution that refers to the different aspects of the alcohol dependence syndrome.

\section{Discussion}

The evaluation of the severity of alcohol dependence is important both for the classification of diagnosed patients as well as for the screening of symptoms even before the disorder is fully manifested. This observation underscores the importance of having a questionnaire such as the SADD adapted for use in Brazil.

In this study, the internal consistency of the SADD as measured using Cronbach's alpha indicates that the items of the scale converge to the same construct. The problem of unreliability is of special concern to researchers dealing with the diagnosis 
Table 1 - Dimensions resulting from Principal Component Analysis of the Short Alcohol Dependence Data (SADD) questionnaire rotated matrix in a sample of hospitalized patients

Loadings

Factor $1 \mathrm{CEV}=\mathbf{2 8 . 3 9 \%}$

2. Is getting drunk more important than your next meal?

0.794

3. Do you plan your day around when and where you can drink?

0.537

6. Do you drink as much as you want irrespective of what you are doing the next day?

0.830

8. Do you know that you won't be able to stop drinking once you start?

0.651

Factor 2 CEV $=14.18 \%$

7. Given that many problems might be caused by alcohol do you still drink too much?

12. After a heavy drinking session do you wake up and retch or vomit?

13. The morning after a heavy drinking session do you go out of your way to avoid people?

0.809

Factor $3 \mathrm{CEV}=11.48 \%$

4. Do you drink in the morning, afternoon and evening?

5. Do you drink for the effect of alcohol without caring what the drink is?

14. After a heavy drinking session do you see frightening things that later you realize were imaginary?

15. Do you go drinking and the next day rind you have forgotten what happened the night before?

Factor $4 \mathrm{CEV}=\mathbf{8 . 2 9 \%}$

10. The morning after a heavy drinking session do you need your first drink to get yourself going?

11. The morning after a heavy drinking session do you wake up with a definite shakiness of your hands?

Factor 5 CEV $=7.21 \%$

1. Do you rind difficulty in getting the thought of drinking out of your mind?

9. Do you try to control your drinking by giving it up completely for days or weeks at a time?

of conditions based on information provided by the patient. To improve reliability, investigators employ repeated measures in the form of symptom items that assess different aspects of a given condition. Therefore, the scores of the scale as a whole tend to display better reliability than the scores of its individual items, since improvement in reliability is a direct function of the number of items in a scale, provided that the items are positively correlated. ${ }^{7}$ Psychometric principles dictate the need to assess the reliability of measures because an unreliable measure is not likely to be valid. Such a measure tends to produce random values that cannot correlate with any criterion of validity. If the items measure the same construct, then the scale's internal consistency can be taken as an index of its reliability. ${ }^{8}$

The Principal Component Analysis resulted in a five-factor solution referring to distinct components of the phenomenon. The possibility of encompassing distinct dimensions of a given condition increases the likelihood of a more adequate assessment of its severity. Since all the items and factors are presumed to tap a single construct, namely 'alcohol dependence', it is common practice to report the overall SADD scale score, which is an implicit acceptance of its conceptual uni-dimensionality. 
Disclosures

\begin{tabular}{|c|c|c|c|c|c|c|c|}
\hline $\begin{array}{l}\text { Writing group } \\
\text { member }\end{array}$ & Employment & $\begin{array}{l}\text { Research } \\
\text { grant }^{1}\end{array}$ & $\begin{array}{c}\text { Other research grant or } \\
\text { medical continuous } \\
\text { education }{ }^{2}\end{array}$ & $\begin{array}{l}\text { Speaker's } \\
\text { honoraria }\end{array}$ & $\begin{array}{l}\text { Ownership } \\
\text { interest }\end{array}$ & $\begin{array}{l}\text { Consultant/ } \\
\text { Advisory } \\
\text { board }\end{array}$ & Other $^{3}$ \\
\hline $\begin{array}{l}\text { Leonardo Quicoli } \\
\text { Rosa-Oliveira }\end{array}$ & UNIFESP & - & - & - & - & - & - \\
\hline $\begin{array}{l}\text { Paula de } \\
\text { Figueiredo Presti }\end{array}$ & UNIFESP & - & - & - & - & - & - \\
\hline $\begin{array}{l}\text { Irene Reali } \\
\text { Antunes }\end{array}$ & UNIFESP & - & - & - & - & - & - \\
\hline $\begin{array}{l}\text { Giovana Canale } \\
\text { Carbonari }\end{array}$ & UNIFESP & - & - & - & - & - & - \\
\hline $\begin{array}{l}\text { Ana Carolina } \\
\text { Imada }\end{array}$ & UNIFESP & - & - & - & - & - & - \\
\hline $\begin{array}{l}\text { Marilia Yuri } \\
\text { Maeda }\end{array}$ & UNIFESP & - & - & - & - & - & - \\
\hline $\begin{array}{l}\text { Dartiu Xavier da } \\
\text { Silveira }\end{array}$ & UNIFESP & - & - & - & - & - & - \\
\hline $\begin{array}{l}\text { Juliana Doering- } \\
\text { Silveira }\end{array}$ & UNIFESP & - & - & - & - & - & - \\
\hline
\end{tabular}

* Modest

** Significant

*** Significant: Amounts given to the author's institution or to a colleague for research in which the author has participation, not directly to the author.

Note: UNIFESP = Universidade Federal de São Paulo.

For more information, see Instructions for Authors.

References

1. Raistrick D, Dunbar G, Davidson R. Development of a questionnaire to measure alcohol dependence. Br J Addict. 1983;78(1):89-95.

2. Davidson R, Raistrick D. The validity of the Short Alcohol Dependence Data (SADD) Questionnaire: a short self-report questionnaire for the assessment of alcohol dependence. BrJ Addict. 1986;81(2):217-22.

3. Davidson R, Bunting B, Raistrick D. The homogeneity of the alcohol dependence syndrome: a factorial analysis of the SADD questionnaire. BrJ Addict. 1989;84(8):907-15.

4. Jorge MR, Masur J. The use of the short-form Alcohol Dependence Data Questionnaire (SADD) in Brazilian alcoholic patients. Br J Addict. 1985;80(3):301-5.

5. Cronbach LJ. Coefficient alpha and the internal structure of tests. Psychometrika. 1951;16:297-303.

6. Child D. The Essentials offactor analysis. 2nd ed. Biddles Ltd., Cassel Educational Ltd.: London; 1990

7. Shrout PE, Yager TJ. Reliability and validity of screening scales: effect of reducing scale length. J Clin Epidemiol. 1989;42(1):69-78.

8. Lord FM, Novick MR. Statistical theories of mental test scores. In: Reading MA, Pickens RW, Johanson C, editors. Addison-Wesley Publishing Company; 1968. 